\title{
Spatial and temporal variations of meiofaunal communities in Cienfuegos Bay, Cuba
}

\author{
Variaciones espaciales y temporales de las comunidades de la meiofauna \\ en la bahía de Cienfuegos, Cuba
}

\section{Lisbet Díaz-Asencio", Maickel Armenteros², Misael Díaz-Asencio ${ }^{1}$, Raúl Fernández-Garcés ${ }^{1}$, Miguel Gómez-Batista ${ }^{1}$ and Carlos Alonso-Hernández ${ }^{1}$}

\author{
${ }^{1}$ Centro de Estudios Ambientales de Cienfuegos, Carretera a Castillo de Jagua Km 1.5, Ciudad Nuclear, Cienfuegos, Cuba \\ ${ }^{2}$ Centro de Investigaciones Marinas, Universidad de la Habana, 16 \# 114, Playa, Ciudad Habana, Cuba \\ lisbet@ceac.cu
}

\begin{abstract}
Resumen.- Se estudió la estructura de la comunidad de la meiofauna en 16 estaciones submareales y en cuatro meses, en la bahía de Cienfuegos, Cuba, para describir sus patrones de distribución así como sus posibles causas. Los contenidos de limo/arcilla (S/C) y materia orgánica (OM) en los sedimentos estuvieron positivamente correlacionados y sus cambios se relacionaron con la variación espacial del ambiente sedimentario a través de las estaciones. El restringido intervalo de salinidad intersticial sugiere un efecto pequeño sobre la meiofauna aún cuando ocurrieron cambios en la salinidad superficial. La densidad y el número de taxa cambiaron entre la estaciones seca y húmeda como respuesta a las condiciones hipóxicas causadas por la estratificación del agua en la estación húmeda. Se determinaron relaciones negativas entre los contenidos de limo/arcilla y materia orgánica con las densidades de la meiofauna, debido posiblemente a los efectos restrictivos causados por la acumulación y oxidación de la materia orgánica. El disturbio físico parece ser un proceso principal que afecta a la meiofauna en algunas estaciones someras sujetas a fuerte oleaje y corrientes de marea. Ningún factor ecológico por sí solo explica la gran variabilidad espacial de las comunidades de la meiofauna en la bahía; probablemente una combinación de varios procesos como la distribución de la producción primaria, la estratificación/mezcla de la columna de agua y el disturbio físico está ocurriendo en la bahía.
\end{abstract}

Palabras clave: Patrones espaciales, estructura comunitaria, Mar Caribe

\section{Introduction}

Semi-enclosed bays are common estuarine systems with high dynamics in sediments and water column. Particularly, the sedimentary environment is important as it is characterized by high fluxes of matter and energy (Heymans \& Baird 1995) and it tends to accumulate pollutants (Birch 2000). Biological processes (e.g., primary production, decomposition of organic matter) strongly determine the sedimentary environment over short time scales (i.e. weeks, months). The inherent variability of these processes in space and time within
Abstract.- The community structure of meiofauna was studied in 16 subtidal sampling stations and in four months in Cienfuegos Bay, Cuba for describing their patterns of distribution, as well as their possible causes. Silt/clay (S/C) and organic matter $(\mathrm{OM})$ contents in sediment were positively correlated, and their changes were related to spatial variation of sedimentary environment across stations. The narrow range of interstitial salinity suggests a slight effect on meiofauna even when changes of surficial salinity occurred. Density and number of taxa changed among dry and wet seasons plausibly as a response to hypoxic conditions due to water stratification in the wet season. Negative relationships were recorded among $\mathrm{S} / \mathrm{C}$ and $\mathrm{OM}$ with meiofaunal densities possibly due to restrictive effects of accumulation and oxidation of organic matter. Physical disturbance appears to be a main process affecting meiofauna in some shallow stations subjected to strong waving and tidal currents. No any single ecological factor explains the large spatial variability of meiofaunal communities in the whole bay; a combination of several processes like distribution of primary production, stratification/mixing of the water column and physical disturbance probably is occurring in the bay.

Key words: Spatial patterns, community structure, Caribbean Sea

bays are one of the most important challenges in their study. The complexity of sedimentary processes in bays suggests undertaking a primary description of compartments (e.g. meiofauna, macrofauna, organic carbon, macrophytes) with a relatively wide spatial and temporal extension in order to estimate the variability and major features of sedimentary environment; a holistic analysis of processes should follow this step.

The meiofauna (here defined as metazoans which size range from 50 to $500 \mathrm{im}$ ) is a faunal group of high importance in the functioning of estuarine systems, especially where soft bottoms predominate and the matter 
and energy fluxes originate mainly from the benthic detrital complex (Heymans \& Baird 1995, RosadoSolórzano \& Gúzman del Próo 1998). In these ecosystems, meiofauna ensures several major ecological roles, among which: i) the decomposition of detritus and the recycling of nutrients; ii) the link between organic matter and higher trophic levels and iii) a significantly contribution to benthic secondary production due to their rapid turnover rate and high metabolic activity (for a review, see Coull 1999).

The spatial and temporal distribution of meiofauna is highly variable and scale-dependent (Higgins \& Thiel 1988, Hodda 1990); hence the assessment of the driving ecological factors is uneasy. In temperate ecosystems, seasonal factors such as temperature and physical disturbance have been proposed to explain the temporal variation of meiofaunal communities (e.g. Emberton 1981, Coull 1986, Hourston et al. 2005, Nozais et al. 2005). In addition, their spatial distribution in shallow habitats is often driven by the grain size of sediment (e.g. Ward 1975, Duplisea \& Dgras 1999, Ndaro \& Ólafsson 1999, Schratzberger et al. 2004) or by food availability (e.g. Ólafsson 1992, Danovaro \& Gambi 2002). In tropical bays, the ecological processes drive meiofauna distribution patterns should be essentially the same, but the scales and details are largely unknown and dependent on local conditions. Therefore, a thorough and reliable description of the structure of meiofaunal communities and their variability is essential for understanding the fundamental ecological processes occurring in the sediments that are driving the functioning of these ecosystems. We expect then changes in community structure following fluctuations in environmental framework, mainly organic and silt/clay content and contamination load.

Recently, the Environmental Studies Centre of Cienfuegos has initiated an extensive monitoring and research environmental programme to describe the major physical, chemical and biological characteristics of Cienfuegos Bay for management purposes. As part of the latter programme, the objectives of the present study were to describe the spatial and temporal distribution patterns of meiofaunal communities of Cienfuegos Bay and to assess the weight of several abiotic parameters as structuring factors. We use a multivariate and univariate statistical framework for testing two general hypotheses: (i) There are no differences among stations/months in the community measurements of meiofauna (e.g. number of taxa; multivariate structure); and (ii) There are no correlative relationships between meiofauna and measured abiotic natural variables (e.g. grain size, organic content, temperature and salinity).

\section{Material and methods}

Study zone

The study was carried out in Cienfuegos Bay (Fig. 1), a semi-enclosed bay situated in the southern central part of Cuba, with a surface area of $90 \mathrm{~km}^{2}$ and an average depth of $14 \mathrm{~m}$. The bay is composed of two relatively welldifferentiated basins, due to the presence of a submerged ridge. The northern basin is subjected to anthropogenic inputs from the outfall of Cienfuegos City, an industrial area (including an oil refinery and a power station) and the freshwater input of the Damuji and Salado rivers. The southern basin, with a considerable lesser human influence, is only affected by inputs from the Caonao and Arimao rivers. The occurrence of riverine and rainfall discharges causes notable seasonal decrease in surficial salinity in all studied stations (Seisdedo \& Muñoz 2005), with marked estuarine characteristics in the rainy season. The bay is characterized by a semidiurnal tidal regime, with average tidal amplitude of $28 \mathrm{~cm}$ (Rodríguez \& Rodríguez 1983). Muddy sediments are present in most parts of the bay (Alonso-Hernández et al. 2006).

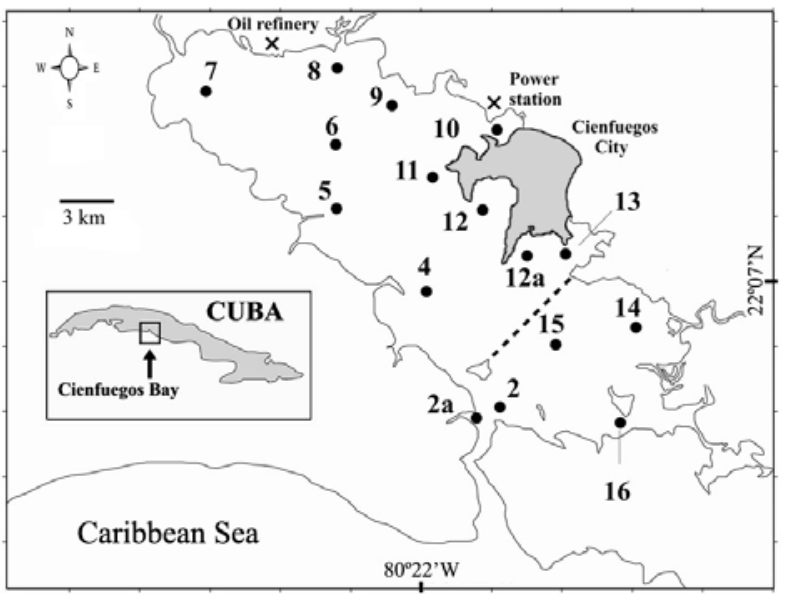

Figure 1

Study zone. Location of 16 sampling stations in Cienfuegos Bay, Cuba. The dashed line indicates the submerged ridge that limited the northern and the southern basin. Major sources of pollutants are indicated

Zona de estudio. Localización de las 16 estaciones de muestreo en la bahía de Cienfuegos, Cuba. La línea discontinua indica el bajo sumergido que limita los lóbulos norte y sur. Se indican las principales fuentes de contaminantes 


\section{Sampling}

Sixteen subtidal stations (Fig. 1) were sampled in the bay during February, May and September 2004 and February 2005 using SCUBA diving. February and September characterize the dry/cold and wet/warm seasons respectively, whereas May represents a transitional month between them. Two sampling units (SU) of sediment were taken at each station for meiofauna analysis (SU: a sediment extraction with a $60-\mathrm{mL}$ plastic corer of $2.9-\mathrm{cm}$ inner diameter). Each corer was carefully placed on the sediment and pushed to $6 \mathrm{~cm}$ deep. The samples were immediately preserved in $4 \%$ formalin buffered with borax to $\mathrm{pH}=7$. A single sample of surficial sediment was taken with a propylene container $(250 \mathrm{~mL})$ for measurement of abiotic variables: organic matter content $(\mathrm{OM})$, silt/clay fraction $(\mathrm{S} / \mathrm{C})$ and interstitial salinity $(\mathrm{S})$. Depth (D) and interstitial temperature at $2 \mathrm{~cm}$ deep inside sediment $(\mathrm{T})$ were registered in situ.

\section{Samples processing}

Meiofaunal samples were sieved through 500- and 50ìm gauze test sieves (Restch) with filtered water (50 ìm sieve). The material retained in the $50 \mathrm{im}$ sieve was used for the extraction of meiofauna, using a flotation technique in high density solution (commercial sugar crystals dissolved in filtered water to $1.18 \mathrm{~g} \mathrm{~cm}^{-3}$ ). The solution was added to sediment (9:1, v:v) and the mixture was vigorously shaken for $1 \mathrm{~min}$, then allowed for sedimentation for $20 \mathrm{~min}$. The supernatant was carefully decanted on a 50-ìm sieve. The procedure was repeated twice for reaching $90 \%$ of extraction efficiency (M. Armenteros, unpublished data). The sorted animals were preserved in $4 \%$ buffered formalin and stained with $1 \%$ alcoholic eosine solution for easier localization of animals. The animals were identified to higher taxa (e.g. Nematoda, Copepoda) and counted under a 56X magnification stereomicroscope.

For determination of the abiotic variables, the samples were centrifuged in order to separate the pore water from sediment. Interstitial salinity in pore water was measured with a hand-held refractometer. Silt/clay fraction was determined by wet sieving through a $63-\mu \mathrm{m}$ sieve to separate the sandy and fine (silt plus clay) fractions. The organic matter content was determined by the WalkeyBlack modified method (Loring \& Rantala 1992). Briefly, the sediment samples were oxidised with $\mathrm{K}_{2} \mathrm{Cr}_{2} 0_{7}$ and $\mathrm{H}_{2} \mathrm{SO}_{4}$, and then chemical titration was carried out in order to determine the quantity of readily oxidizable organic matter (the method excludes compounds such as graphite and coal).

\section{Data analysis}

Data were analysed using univariate and multivariate methods with Statistica ${ }^{\circ} 6.0$ and PRIMER 5.2.9 (Clarke \& Warwick 2001) softwares. Ordination of samples (combinations of station-month) on basis of abiotic variables was carried out by correlation-based principal component analysis (PCA) using standardized data. Ordination of samples on basis of averaged density data was performed by non-metric multidimensional scaling (MDS) with the identification of animals to higher taxa. Similarity matrix among meiofaunal samples was built using the Bray-Curtis similarity index and fourth root transformation of data. Two-way analyses of variance (ANOVA) were carried out for detecting differences among stations and months for the following variables: number of taxa, nematode density and total density. Data were log-transformed to reduce the correlation between mean and variance. Two-way analysis of similarity (ANOSIM) was performed for testing differences among months and among stations in multivariate structure of communities. The low number of replicates (possible permutations $=81$ ) by station prevented the interpretation of pairwise tests among stations.

The relationships between biotic and abiotic multivariate patterns were explored by BIOENV procedure (Clarke \& Warwick 2001). Also, Pearson's Product-Moment correlation coefficient was determined between abiotic and biotic (total density, nematode density, and $\%$ nematodes) variables.

\section{Results}

\section{Meiofaunal communities}

Twelve meiofaunal taxa were recorded: Nematoda, Copepoda, Kinorhyncha, Rotifera, Sipuncula, Priapulida, Polychaeta, Oligochaeta, Ostracoda, Amphipoda, Decapoda and Tanaidacea. The contribution of each taxon to total density (mean $\pm \mathrm{SD}$ ) indicated a strong dominance of nematodes $(94.8 \pm 7.1 \%)$ whereas copepods contributed for only $3.3 \pm 4.9 \%$. A significant interaction (ANOVA; $P<0.01$ ) was observed between months and stations in the number of major taxa. The minimum number of taxa in one sample was one (nematodes) and the maximum was seven. A significant correlation was found between number of taxa and density of meiofauna $(\mathrm{r}=0.52, P<0.05, \mathrm{n}=60)$.

The two-way ANOSIM global test indicated significant differences among months $(\mathrm{R}=0.56, P=0.001$, 999 permutations) and among stations $(\mathrm{R}=0.62, P=0.001$, 999 permutations). Pairwise comparisons showed 


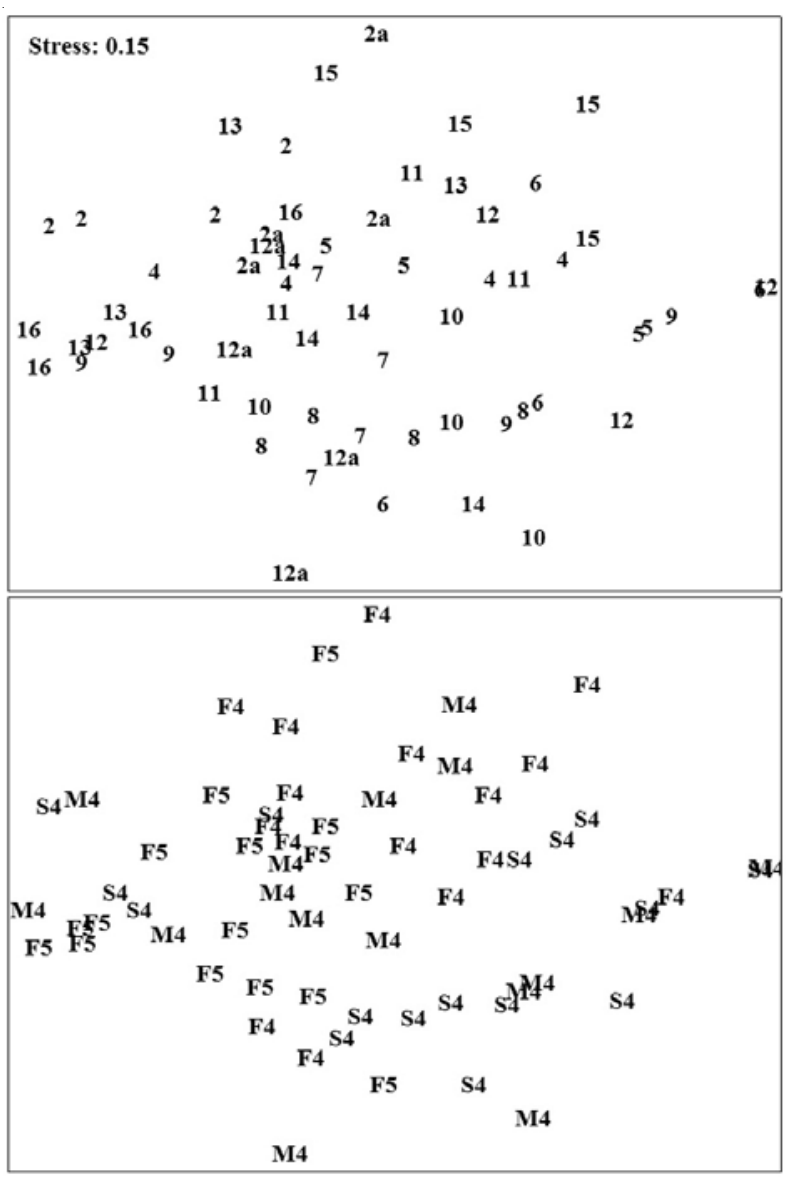

Figure 2

Multidimensional scaling ordination plot of 16 stations in four months on basis of averaged density data of meiofauna transformed as fourth root. For clearer representation the same plot was labelled by stations (upper graph) and by months (below graph). Labels: F4=February 2004, M4 = May 2004, S4 = September 2004 and F5 = February 2005

Ordenación numérica por escalado multidimensional de las 16 estaciones en los cuatro meses en base a datos de densidad de la meiofauna transformados como raíz cuarta. Para una representación más clara, en el mismo gráfico se han indicado las estaciones (superior) y los meses (inferior).

Etiquetas: F4 = Febrero 2004, M4 = Mayo 2004, S4 $=$ Septiembre 2004 y F5 = Febrero 2005

significant differences between all pairs of months (average $\mathrm{R}=0.58, P<0.01,999$ permutations). However, the MDS ordination plot did not show any clear temporal and spatial trends across months and stations, respectively (Fig. 2).

Significant differences (two-way ANOVA, $P<0.01$ ) were determined between stations, months and in the
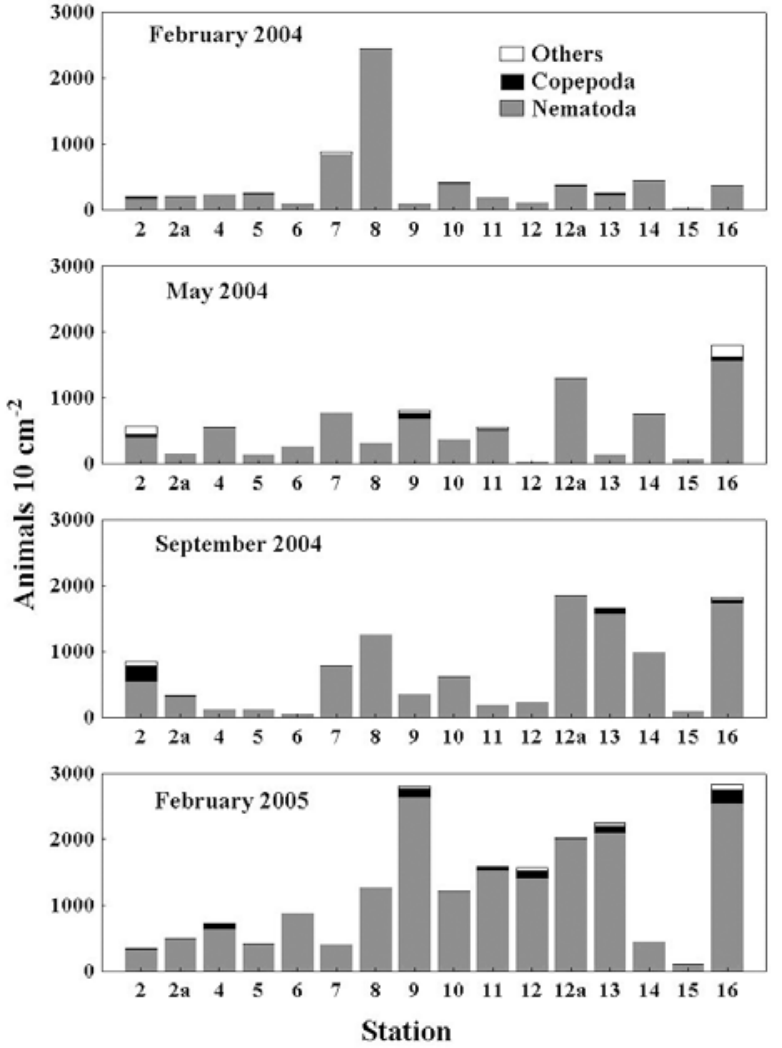

Figure 3

\section{Average $(n=2)$ density of meiofauna in 16 stations and four months in Cienfuegos Bay}

Densidad promedio $(n=2)$ de la meiofauna en 16 estaciones y cuatro meses en la bahía de Cienfuegos

interaction for nematode density and total density. A notable temporal and spatial variation in meiofaunal communities occurred; however, there was no clear trend in density across stations (Fig. 3). Generally, higher values of density were found in almost all stations at February 2005 (average -across all stations- value of total density was $1212.5 \pm 889.7$ animals $10 \mathrm{~cm}^{-2}$. The total density for the other months showed lower values (February 2004: 415.2 \pm 578.8; May 2004: 539.6 \pm 478.4; and September 2004: $705.4 \pm 638.3$ animals $\left.10 \mathrm{~cm}^{-2}\right)$.

\section{Abiotic variables}

The average value $(n=64)$ and the range of values of the abiotic factors for the four months and 16 stations were as follows: depth $(8.0 \mathrm{~m} ; 1.8-16.0 \mathrm{~m})$, interstitial temperature $\left(26.9^{\circ} \mathrm{C} ; 22.0-30.6^{\circ} \mathrm{C}\right)$, silt/clay fraction $(73.5 \% ; 11.8-100 \%)$, organic matter content $(3.74 \%$; $0.90-6.62 \%$ ) and interstitial salinity (36 psu; 33-38 psu). 
A principal component analysis including depth, temperature, silt/clay fraction, and organic matter content explained $66.2 \%$ of the total variability with the first two components. Due to discontinuities in the data set, interstitial salinity values were excluded. The equations of the axes are: $\mathrm{PC} 1=0.68 \mathrm{~S} / \mathrm{C}+0.67 \mathrm{OM}+0.25 \mathrm{D}-$ $0.15 \mathrm{~T}$; $\mathrm{PC} 2=0.93 \mathrm{~T}-0.29 \mathrm{D}+0.16 \mathrm{OM}+0.15 \mathrm{~S} / \mathrm{C}$ (Fig. 4).

The variation along $\mathrm{PC} 1$ is related to a gradient in grain size and organic matter content across stations (Fig.
4). A group of stations (stations 5, 6, 7, 8, 12 and 15) displayed sediment characterized by a high proportion of fine sediment $(\mathrm{S} / \mathrm{C}$ mean $\pm \mathrm{SD}: 93.0 \pm 7.1 \%)$ and of organic matter $(4.68 \pm 0.95 \%)$. Another group (stations 2, 2a, 9, 10, 13 and 16) were constituted of sandy sediments (S/C: $53.2 \pm 31.0 \%)$ and had a lesser quantity of organic matter $(2.74 \pm 1.34 \%)$. The latter group also showed higher variability among months (Fig. 5). There was a significant correlation between silt/clay fraction and organic matter content $(\mathrm{r}=0.63, P<0.05, \mathrm{n}=60)$.
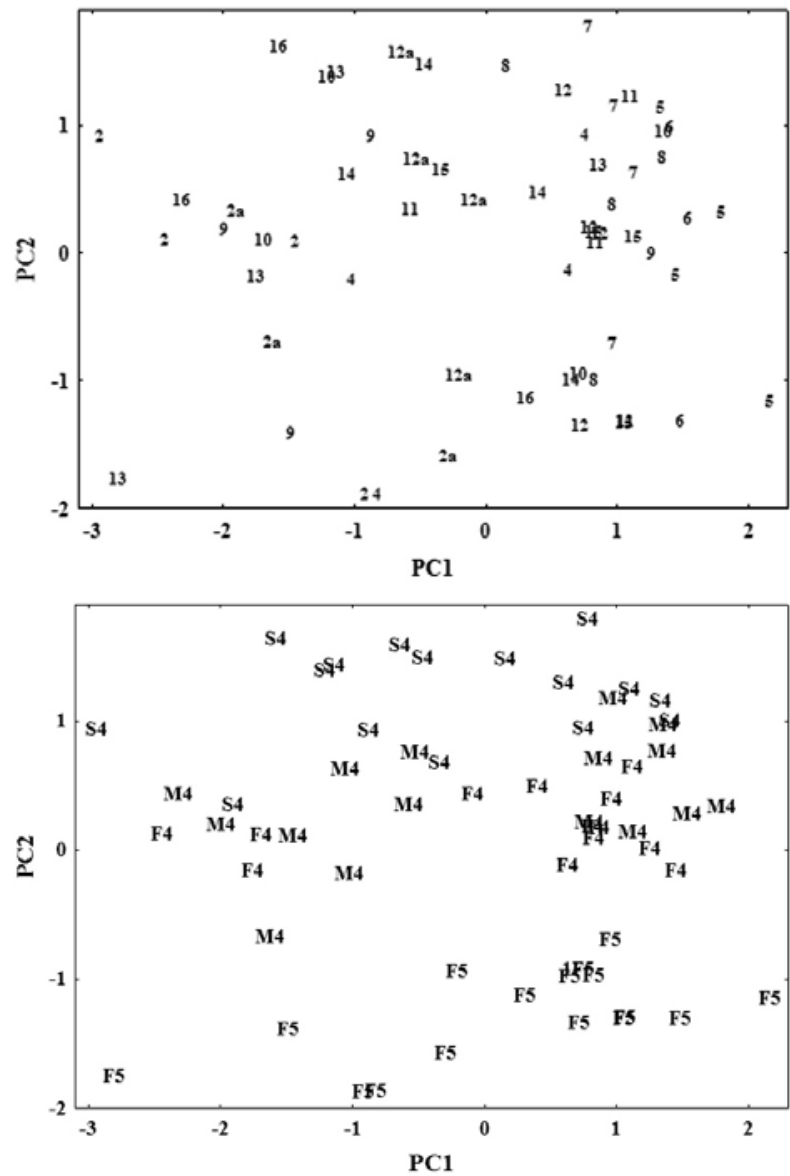

Figure 4

Principal component analysis ordination plot of 16 stations in four months on basis of abiotic variables: silt/clay fraction (S/C), organic matter content (OM), depth (D) and interstitial temperature (T). The equation of axes: PC1=0.68 S/C + 0.67 OM + 0.25 D

$-0.15 \mathrm{~T}$; PC2=0.93 T - 0.29 D + 0.16 OM + 0.15 S/C. Percentage of explained variance by two first axes: $66.2 \%$. For clearer representation the same plot was labelled by stations (upper graph) and by months (below graph). F4 =February 2004, M4 = May 2004, S4 = September 2004 and F5 = February 2005

Ordenación numérica por análisis de componentes principales de las 16 estaciones en los cuatro meses en base a las variables abióticas: fracción limo/arcilla $(\mathrm{S} / \mathrm{C})$, contenido de material orgánica $(\mathrm{OM})$, profundidad (D) y temperatura intersticial (T). Las ecuaciones de los ejes: $\mathrm{PC} 1=0.68 \mathrm{~S} / \mathrm{C}+0.67 \mathrm{OM}+0.25 \mathrm{D}-0.15 \mathrm{~T}$; PC2 $=0.93 \mathrm{~T}-0.29 \mathrm{D}+0.16 \mathrm{OM}+0.15 \mathrm{~S} / \mathrm{C}$. El porcentaje de la varianza explicada para los dos primeros ejes: 66.2\%. Para una representación más clara, en el mismo gráfico se indican las estaciones (superior) y los meses (inferior). F4 = Febrero 2004, M4 = Mayo 2004, 


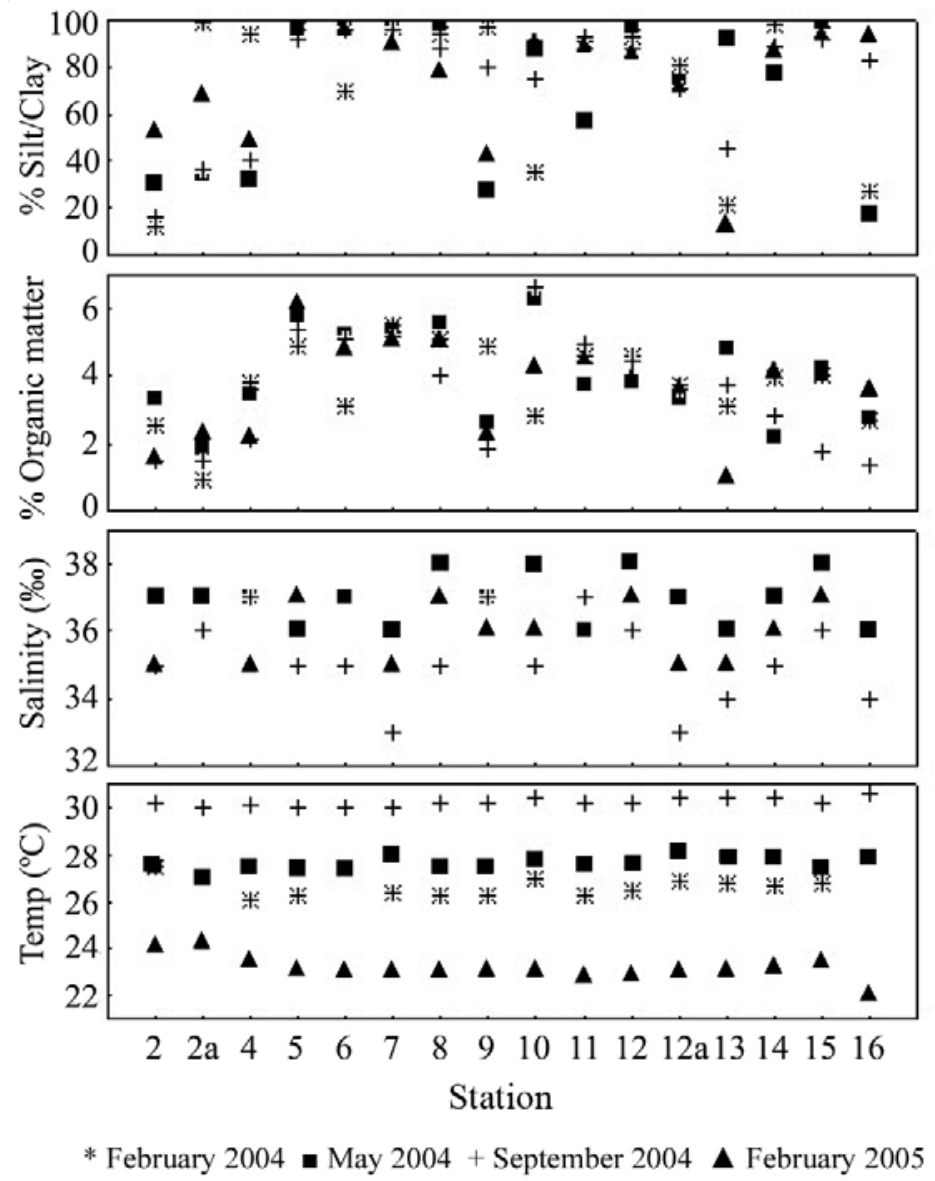

Figure 5

\section{Abiotic factors measured in $\mathbf{1 6}$ stations and four months in Cienfuegos Bay. The values not shown are due to discontinuities in the data set}

Factores abióticos medidos en las 16 estaciones y los cuatro meses en la bahía de Cienfuegos. Los valores no mostrados se deben a discontinuidades en el conjunto de datos.

Ordination of samples along PC2 was mainly due to temperature (Fig. 4), suggesting seasonal distinction between sampling months. A one-way ANOVA detected significant differences regarding temperature among months $(P<0.001)$. The mean value of temperature (all stations together) was highest $\left(30.2 \pm 0.2^{\circ} \mathrm{C}\right)$ in September 2004 and lowest in February $2005\left(23.1 \pm 0.5^{\circ} \mathrm{C}\right)$. Difference in temperature between February 2004 (26.6 $\pm 0.4^{\circ} \mathrm{C}$ ) and February 2005 indicated strong annual variability (Fig. 5). Interstitial salinity displayed a narrow range of variation; in general September 2004 showed the lowest values (35 $\pm 1 \mathrm{psu}$ ) and May 2004 the highest ones (37 \pm 1 psu) (Fig. 5).
BIOENV procedure did not allow the determination of correlation between multivariate community structure and any combination of the abiotic variables (interstitial temperature, depth, silt/clay fraction and sediment organic matter content). Univariate correlations between total density of meiofauna and abiotic variables (Fig. 6) showed significant correlations $(P<0.05, \mathrm{n}=60)$ with depth $(\mathrm{r}=-0.53)$, temperature $(\mathrm{r}=-0.28)$, and organic matter $(\mathrm{r}=-$ $0.26)$. Significant correlations $(P<0.05, \mathrm{n}=60)$ between number of major taxa and abiotic factors (Fig. 7) were also found for depth $(\mathrm{r}=-0.34)$; temperature $(\mathrm{r}=-0.35)$; organic matter $(\mathrm{r}=-0.51)$; and silt/clay $(\mathrm{r}=-0.55)$. 


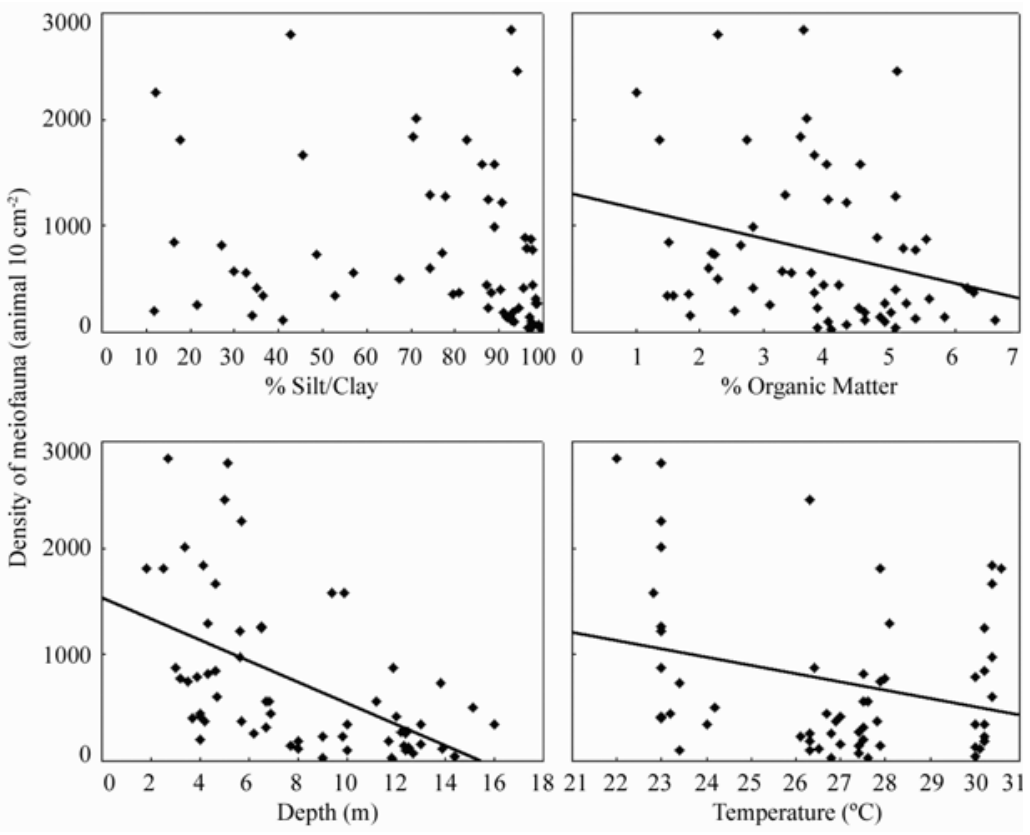

Figure 6

Scatters plots $(\mathrm{N}=60)$ of total density of meiofauna versus four abiotic variables measured in 16 stations and four months in Cienfuegos Bay. Trend line is depicted where significant correlation exist

Gráficos de dispersión $(\mathrm{N}=60)$ de la densidad total de la meiofauna contra las cuatro variables abióticas medidas en las 16 estaciones y en los cuatro meses en la Bahía de Cienfuegos. Se muestra la línea de tendencia cuando existe correlación significativa

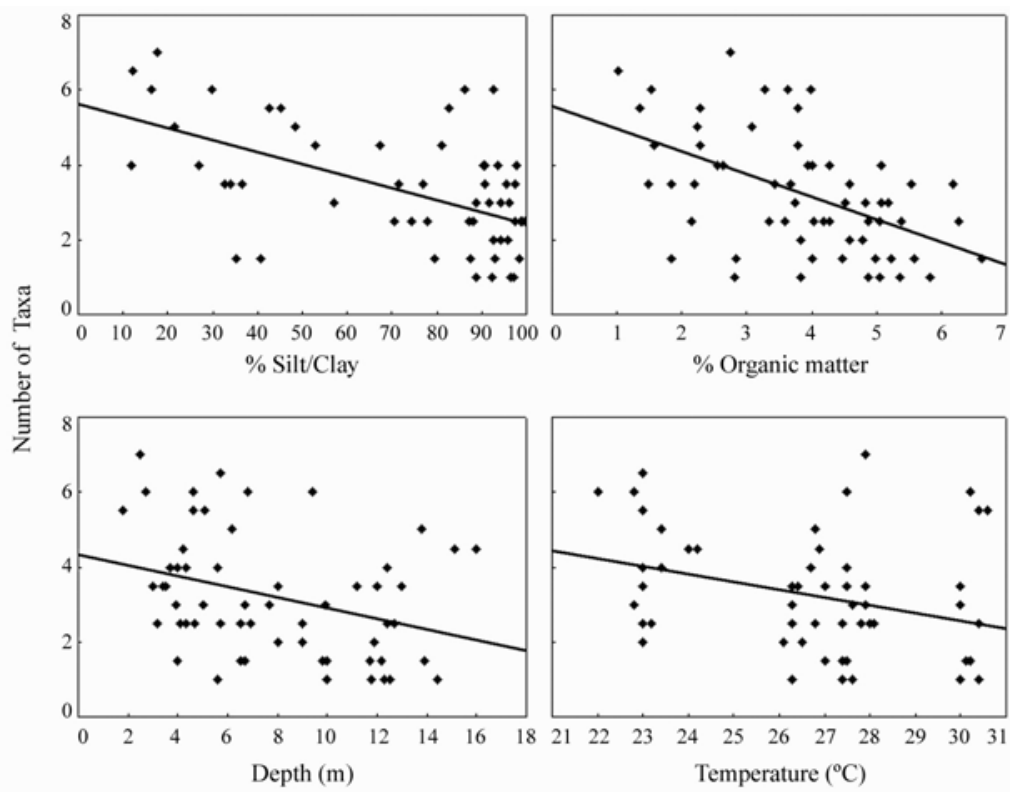

Figure 7

Scatters plots $(\mathrm{N}=60)$ of number of meiofaunal taxa versus four abiotic variables measured in 16 stations and four months in Cienfuegos Bay. Trend line is depicted where significant correlation exist

Gráficos de dispersión $(\mathrm{N}=60)$ del número de taxa de la meiofauna contra las cuatro variables abióticas medidas en las 16 estaciones y en los cuatro meses en la bahía de Cienfuegos. Se muestra la línea de tendencia cuando existe correlación significativa 


\section{Discussion}

The notable spatial and temporal variability in measured abiotic variables indicates a highly dynamic sedimentary environment in Cienfuegos Bay. Meiofaunal communities are subjected to these temporal (e.g. in temperature) and spatial (e.g. in organic content and grain size) changes; therefore, a high variation in these communities should be expected as a response to environmental changes.

Several authors have pointed out that meiofauna community structure is strongly determined by the sedimentary environment (Hicks \& Coull 1983, Higgings \& Thiel 1988, Coull 1999, Danovaro et al. 2004). Particularly, salinity, temperature, grain size and organic matter content are thought being key factors in explaining spatial and temporal variation of meiofauna communities.

Effects of salinity on meiofauna have been reported by Yamamuro (2000) and Ólafsson et al. (2000); however, the relatively narrow range of interstitial salinity observed in the present study suggests that, if any, this variable could only have a limited effect on meiofauna. Pore water salinity is conservative, even when freshwater pools are present on the sediment (Ólafsson et al. 2000), which explains the slight fluctuations in interstitial salinity in Cienfuegos Bay in comparison with wider changes measured in surficial waters (range: 27-35 psu).

To the best of our knowledge, effects of temporal (month-scale) changes of temperature on meiofauna have never been studied in semi-enclosed tropical bays. There are however information available from temperate estuaries, where the relationships between temperature and meiofauna have been explained by: (i) events of nematode reproductive blooms (Heip et al. 1985, Moens \& Vincx 2000); (ii) increase of food availability (Danovaro \& Gambi 2002); and (iii) stratification of the water column in the warmer season, provoking a reduction of physical disturbance (Hall 1994). All these benthic processes tend to enhance the abundance and diversity of the meiofaunal communities when temperature increases; and they are strongly related to seasonality in temperate regions.

Density and number of taxa change among months in Cienfuegos Bay; a plausible explanation is that levels of dissolved oxygen in bottom water during the wet and warm season are low in most of our sampling stations (< $3.0 \mathrm{mg} \mathrm{L}^{-1}$ after Seisdedo \& Muñoz 2005). Hypoxic conditions in the bottom water are due to the stratification of the water column and this becomes the sediment oxygenation in a limiting factor for meiofauna (Papadopoulou et al. 1998, Sandulli \& Nicola-Giudici 1989). Other processes with monthly variation as tropical storms and primary production probably influence the meiofaunal communities too but we can not clarify these relationships in the present study.

As was expected due to the known affinity of organic matter for clays (Snelgrove \& Butman 1994), a positive correlation was observed between silt/clay fraction and organic matter in the sediments of Cienfuegos Bay. In addition, negative relationships were recorded between silt/clay fraction and organic matter and meiofauna density and number of taxa.

The presence of organic matter in sediment has two kind of effects on meiofauna: (i) a stimulating effect due to the increase of food resources for detritivorous fauna (Danovaro et al. 2000) and (ii) a restrictive one due to the decrease of oxygen content in pore water (Mazzola et al. 2000). During the present study, the high spatial (across 16 sampling stations) and temporal (across four months) variability in sedimentary processes prevented the detection of strong relationships between grain size or organic matter and meiofauna (i.e. low correlation values were obtained). However, during the four sampled months, some out of the deep stations (e.g. 4, 5, 6, and 15) demonstrated high values of silt/clay and organic content and low densities of meiofauna, hence supporting the aforementioned restrictive effect of accumulation and oxidation of organic matter.

The elevated spatial variations (in scale of hundreds of meters) of meiofaunal communities could be explained, at least partially, by changes in food availability due to differences in accumulation of detritus across stations. In fact, the distribution of phytoplankton is a highly variable biological process across Cienfuegos Bay (A. Moreira, pers. comm.) and it could determine a high variability in quantity of phytoplankton-derived detritus. The small number of samples $(n=2)$ obviously difficult the interpretation of results since we cannot assess precisely the variability in community structure. However, despite of low level of replication (low statistical power) significant differences were detected indicating clear changes among stations and months.

As previously proposed by some authors (Palmer 1988, Schratzberger \& Warwick 1998, Dernie et al. 2003), physical reworking of sediment could also be a limiting factor for meiofaunal densities. For example, station 2, which is subjected to strong currents and waving (A. Muñoz, pers. comm.), was characterized by low densities of meiofauna at all sampling dates.

There are evidences of contamination by heavy metals in areas of the Cienfuegos Bay close to the power station, the city and outfalls of the main rivers (Pérez et al. 2004). 
Correlative analyses among contamination and meiofaunal data (not shown in the present study) suggest that pollution-related response of meiofauna is not the main process that shaped the community structure in the entire bay. However, a higher level of taxonomic resolution for the identification of dominant taxa (i.e. nematodes) should show species-specific responses of meiofauna to natural and anthropogenic disturbance. For meiofaunal nematodes, a taxonomic level of genus appears to show clear responses to disturbance (Warwick 1988, 1993).

In summary, we rejected the two proposed null hypothesis about no differences among stations/months in meiofaunal communities; and about no relationships between meiofauna and abiotic environment. The processes that rule meiofaunal temporal changes (monthscale) would be related to hypoxic conditions produced by stratification of the water column during the rainy period. Spatial variation (station-scale) of meiofauna was related to distribution of grain size and organic content; a process of organic matter oxidation probably had negative influence on meiofauna in some deep-muddy stations.

\section{Acknowledgments}

We would like to thank H. Duarte for his technical assistance with the scuba diving. We thank M. Vincx, for her valuable comments on an early version of the manuscript and M. Warnau, who improved the final manuscript and help us with English language. We also thank the corrections suggested by the unknown referees. The study was supported by the Cuban Ministry of Science, Technology and Environment, Provincial Dependency of Cienfuegos, Project $N^{\circ}$ 6.03.20.

\section{Literature cited}

Alonso-Hernández CM, M Díaz-Asencio, A MuñozCaravaca, R Delfanti, C Papucci, O Ferreti \& C Crovato. 2006. Recent changes in sedimentation regime in Cienfuegos Bay, Cuba, as inferred from ${ }^{219} \mathrm{~Pb}$ and ${ }^{137} \mathrm{Cs}$ vertical profiles. Continental Shelf Research 26: 153-167.

Birch GF. 2000. Marine pollution in Australia, with special emphasis on central New South Wales estuaries and adjacent continental margin (review). International Journal of Environmental Pollution 13: 573-607.

Clarke KR \& RM Warwick. 2001. Change in marine communities: an approach to statistical analysis and interpretation, 176 pp. PRIMER-E Ltd, Plymouth.

Coull BC. 1986. Long-term variability of meiobenthos: value, synopsis, hypothesis generation and predictive modelling. Hydrobiologia 42: 271-279.

Coull BC. 1999. Role of meiofauna in estuarine soft-bottom habitats. Australian Journal of Ecology 24: 327-343.
Danovaro R \& C Gambi. 2002. Biodiversity and trophic structure of nematode assemblages in seagrass systems: evidence for a coupling with changes in food availability. Marine Biology 141: 667-677.

Danovaro R, C Gambi, E Manini \& M Fabiano. 2000. Meiofauna response to a dynamic river plume front. Marine Biology 137: 359-370.

Danovaro R, MC Gambi, S Mirto, R Sandulli \& VU Ceccherelli. 2004. Meiofauna. In: Gambi C \& M Dappiano (eds). Mediterranean marine benthos: a manual of methods for its sampling and study, pp. 55-97. Societa Italiana Di Biologia Marina, Genova.

Dernie KM, MJ Kaiser, EA Richardson \& RM Warwick. 2003. Recovery of soft sediment communities and habitats following physical disturbance. Journal of Experimental Marine Biology and Ecology 285/286: 415-434.

Duplisea DE \& A Drgas. 1999. Sensitivity of a benthic, metazoan, biomass size spectrum to differences in sediment granulometry. Marine Ecology Progress Series 177: 73-81.

Emberton KCJ. 1981. Season-depth relations in subtidal meiofauna of Cape Cod Bay. Estuaries 4: 121-126.

Hall SJ. 1994. Physical disturbance and marine benthic communities: life in unconsolidated sediments. Oceanography and Marine Biology: an Annual Review 32: 179-239.

Heip C, M Vincx \& G Vranken. 1985. The ecology of marine nematodes. Oceanography and Marine Biology: an Annual Review 23: 399-489.

Heymans JJ \& D Baird. 1995. Energy flow in the Kromme Estuarine Ecosystem, St Francis Bay, South Africa. Estuarine, Coastal and Shelf Science 41: 39-59.

Hicks GRF \& BC Coull. 1983. The ecology of marine meiobenthic harpacticoid copepods. Oceanography and Marine Biology: an Annual Review 21: 67-175.

Higgings RP \& H Thiel. 1988. Introduction to the study of meiofauna, 488 pp. Smithsonian Institution Press, London.

Hodda M. 1990. Variation in estuarine littoral nematode populations over three spatial scales. Estuarine, Coastal and Shelf Science 30: 325-340.

Hourston M, RM Warwick, F J Valesini \& IC Potter. 2005. To what extent are the characteristics of nematode assemblages in nearshore sediments on the west Australian coast related to habitat type, season and zone? Estuarine, Coastal and Shelf Science 64: 601-612.

Loring DH \& RTT Rantala. 1992. Manual for the geochemical analyses of marine sediments and suspended particulate matter. Earth-Science Reviews 32: 235-283.

Mazzola A, S Mirto, T La Rosa, M Fabiano \& R Danovaro. 2000. Fish-farming effects on benthic community structure in coastal sediments: analysis of meiofaunal recovery. ICES Journal of Marine Science 57: 1454-1461.

Moens $\mathbf{T}$ \& $\mathbf{M}$ Vincx. 2000. Temperature and salinity constraints on the life cycle of two brackish-water nematode species. Journal of Experimental Marine Biology and Ecology 243: 115-135. 
Ndaro SGM \& E Ólafsson. 1999. Soft-bottom fauna with emphasis on nematode assemblage structure in a tropical intertidal lagoon in Zanzibar, eastern Africa: I. Spatial variability. Hydrobiologia 405: 133-148.

Nozais C, R Perissinotto \& G Tita. 2005. Seasonal dynamics of meiofauna in a South African temporarily open/closed estuary (Mdloti Estuary, Indian Ocean). Estuarine, Coastal and Shelf Science 62: 325-338.

Ólafsson E. 1992. Small-scale spatial distribution of marine meiobenthos: the effects of decaying macrofauna. Oecologia 90: $37-42$.

Ólafsson E, S Carlstrom \& SGM Ndaro. 2000. Meiobenthos of hypersaline tropical mangrove sediment in relation to spring tide inundation. Hydrobiologia 426: 57-64.

Palmer MA. 1988. Epibenthic predators and marine meiofauna: separating predation, disturbance and hydrodynamic effects. Ecology 69: 1251-1259.

Papadopoulou KN, I Karakassis \& A Otegui. 1998. Harbour meiofaunal communities and organic enrichment effects. Fresenius Environmental Bulletin 7: 34-41.

Pérez S, CM Alonso-Hernández, R Morabito, C Brunori \& C Cremisini. 2004. Evaluación de la distribución de metales en los sedimentos superficiales de la bahía de Cienfuegos, Cuba. Revista de Investigaciones Pesqueras 1, Edición Especial: 1-14.

Rodríguez JP \& JE Rodríguez. 1983. Las mareas en las costas cubanas. Reporte de Investigación del Instituto de Oceanología 6: 1-37.

Rosado-Solórzano R \& SA Guzmán del Próo. 1998. Preliminary trophic structure model for Tampamachoco lagoon, Veracruz, Mexico. Ecological Modelling 109: 141154.
Sandulli R \& M Nicola-Giudici. 1989. Effects of organic enrichment on meiofauna: a laboratory study. Marine Pollution Bulletin 20: 223-227.

Schratzberger M \& RM Warwick. 1998. Effects of physical disturbance on nematode communities in sand and mud: a microcosm experiment. Marine Biology 130: 643-650.

Schratzberger M, SG Bolam, P Whomersley, K Warr \& HL Rees. 2004. Development of a meiobenthic nematode community following the intertidal placement of various types of sediment. Journal of Experimental Marine Biology and Ecology 303: 79-96.

Seisdedo M \& A Muñoz. 2005. Efecto de las precipitaciones en la calidad de las aguas de la bahía de Cienfuegos. Revista Cubana de Meteorología 12: 64-67.

Snelgrove PVR \& CA Butman. 1994. Animal-sediment relationships revisited: cause versus effects. Oceanography and Marine Biology: an Annual Review 32: 111-177.

Ward AR. 1975. Studies on the sublittoral free-living nematodes of Liverpool Bay. II. Influence of sediment composition on the distribution of marine nematodes. Marine Biology 30: 217-225.

Warwick RM. 1988. The level of taxonomic discrimination required to detect pollution effects on marine benthic communities. Marine Pollution Bulletin 19: 259-268.

Warwick RM. 1993. Environmental impact studies on marine communities: pragmatical considerations. Australian Journal of Ecology 18: 63-80.

Yamamuro M. 2000. Abundance and size distribution of sublittoral meiobenthos along estuarine salinity gradients. Journal of Marine Systems 26: 135-143.

Recibido el 10 de julio de 2008 y aceptado el 1 de octubre de 2008 